\title{
KEDUDUKAN HUKUM ANAK ANGKAT TERHADAP HARTA WARIS ORANG TUA MENURUT HUKUM POSITIF
}

\author{
Oleh \\ Joejoen Tjahjani \\ Dosen Fakultas Hukum Universitas Islam Lamongan
}

\begin{abstract}
ABSTRAK
Tulisan ini merupakan hasil penelitian lapangan dengan permasalahan yang akan dibahas yaitu, Bagaimana pengangkatan anak menurut Peratuan Pemerintah No 54 Tahun 2007? dan Bagaimana kedudukan harta waris orang tua terhadap anak angkat menurut Hukum Positif?

Untuk menjawab permasalahan di atas penulis menggunakan metode penelitian yuridis normatif (hukum normatif), yaitu suatu langkah atau prosedur penelitian ilmiah untuk menemukan kebenaran berdasarkan logika keilmuan hukum dari sisi normatifnya. Penelitian ini menggunakan pendekatan perundang-undangan (statute approach), pendekatan kasus (case approach), pendekatan historis (historical approach), pendekatan komparatif (comparative approach) dan pendekatan konseptual (conceptual approach), Hasil penelitian ini menyimpulkan bahwa, Menurut PP No. 54 Tahun 2007 mengatur tentang Tata Cara sahnya pengangkatan anak yang harus menempuh jalur formal. Eksistensi dari pada PP tersebut juga mengenal pengangkatan anak secara adat istiadat masayarakat setempat, disamping pengangkatan anak secara undang-undang. Sehingga kedudukan anak yang diangkat secara adat juga diakui secara sah. Sedangkan Kedudukan anak angkat menurut hukum positif tetap sebagai anak angkat yang sah berdasarkan keputusan pengadilan dengan tidak memutuskan hubungan nasab dengan orang tua kandungnya. Untuk Kedudukan Anak Angkat Terhadap Harta Waris Orang Tua menurut Hukum Positif alangkah baiknya orang tua angkat memberi hak yang sama terhadap anak angkat termasuk juga mengenahi kesamaan hak dan kewajiban yang dimiliki oleh anak angkat dalam warisan harta orang tua.
\end{abstract}

Kata Kunci : Anak Angkat, Harta Waris, Hukum Positif.

\section{A. PENDAHULUAN}

Manusia adalah makhluk ciptaan Tuhan yang paling sempurna diantara makhluk hidup lainnya. Pada dasarnya mereka diberikan kelebihan berupa akal dan fikiran agar dapat menjalani kehidupan serta memanfaatkan seluruh isi dunia ini. Sudah menjadi kodrat seorang manusia untuk hidup berdampingan, karena setiap manusia pasti sudah ditakdirkan untuk hidup saling berpasang-pasangan dan berusaha untuk meneruskan keturunan dengan cara melangsungkan perkawinan. Adanya suatu perkawinan menjadikan tempat bagi manusia untuk mengabdikan diri satu dengan yang lain serta saling menghormati perasaan pasangannya nanti. Perkawinan merupakan tali ikatan yang melahirkan keluarga sebagai dasar masyarakat dan Negara yang pada dasarnya suatu tali ikatan yang suci itu akan menjadikan momok dasar setiap pasangan untuk saling berkomitmen.

Tujuan pengangkatan anak terbesar dalam pengangkatan anak adalah untuk semata - mata meningkatkan kesejahteraan anak angkat itu sendiri terutama dalam 
kedudukannya dalam mendapatkan harta waris dari orang tua angkatnya.

$$
\text { Definisi Pengangkatan }
$$

Anak terdapat dalam Peraturan Pemerintah Nomor 54 tahun 2007 Pasal 1 butir 2 tentang Pengangkatan anak, berbunyi; "Pengangkatan anak adalah suatu perbuatan hukum yang mengalihkan seorang anak dari lingkungan kekuasan orang tua, wali yang sah atau orang lain yang bertanggung jawab atas perawatan, pendidikan dan membesarkan anak tersebut ke dalam lingkungan keluarga orang tua angkat.

Tata cara adopsi anak telah diatur dalam Undang-Undang No. 23 Tahun 2002 tentang Perlindungan Anak yang didukung oleh Peraturan Pemerintah Nomor 54 Tahun 2007 yang dijelaskan lebih rinci dalam Peraturan Menteri Sosial Nomor 110 Tahun 2009 tentang Persyaratan Pengangkatan Anak.

\section{Peraturan}

tersebut

menyebut bahwa pengangkatan anak hanya dapat dilakukan untuk kepentingan terbaik bagi anak, dan tidak boleh memutus hubungan darah antara anak yang diangkat dengan orang tua kandungnya ${ }^{7}$.

Indonesia adalah negara yang memiliki berbagai macam keanekaragaman, antara lain adalah keanekaragaman hayati, budaya, dan adat istiadat. Adat istiadat yang terdapat di Indonesia berbeda-beda dari satu daerah ke daerah yang lain sehingga kemudian perbedaan inilah yang menimbulkan suatu norma yang kemudian menjadi hukum di dalam kelompok masyarakat adat tersebut, salah satunya mengenai hukum adat waris, yang kemudian dikaitkan dengan bagaimana dengan kedudukan

\footnotetext{
${ }^{7}$ Irma Setyowati Soemitro, Aspek Perlindungan Anak, Bumi Aksara: Jakarta, 1990. Hal 51
}

anak angkat dalam mewarisi harta orang tua angkatnya ${ }^{8}$.

\section{B. RUMUSAN MASALAH}

1. Bagaimana pengangkatan anak menurut Peratuan Pemerintah No 54 Tahun 2007?

2. Bagaimana kedudukan harta waris orang tua terhadap anak angkat menurut Hukum Positif?

\section{PEMBAHASAN}

Metode Penelitian

Berdasarkan perumusan masalah dan tujuan penelitian yang sudah dibahas oleh penulis, maka tipe penelitian hukum yang digunakan oleh penulis adalah penelitian yuridis normatif (hukum normatif). Metode penelitian hukum normatif adalah suatu prosedur penelitian ilmiah untuk menemukan kebenaran berdasarkan logika keilmuan hukum dari sisi normatifnya. ${ }^{9}$

Oleh karena itu penelitian hukum ini difokuskan untuk mengkaji penelitian hukum tentang kaidahkaidah atau norma-norma dalam hukum positif, yakni norma hukum yang terkait dengan kepastian hukum anak angkat.

Hasil Penelitian

Anak sering kali dipersepsikan sebagai manusia yang masih berada pada tahap perkembangan sehingga belum dapat dikatakan sebagai manusia yang utuh. Dengan keterbatasan usia yang tentunya berpengaruh pada pola pikir dan tindakan, anak belum mampu untuk memilah antara hal yang baik dan buruk.

Dalam sudut pandang yang dibangun oleh agama khususnya dalam hal ini adalah agama Islam, anak merupakan makhluk yang dhaif

\footnotetext{
${ }^{8}$ Tolib Setiady, Intisari Hukum Adat Indonesia, Alfabeta, Bandung, 2009. Hal-281.

${ }^{9}$ Johny Ibrahim, Teori \& Metode Penelitian Hukum Normatif. Hal 27.
} 
dan mulia, yang keberadaannya adalah kewenangan dari kehendak Allah SWT dengan melalui proses penciptaan.43 Oleh karena anak mempunyai kehidupan yang mulia dalam pandangan agama Islam, maka anak harus diperlakukan secara manusiawi seperti diberi nafkah baik lahir maupun batin, sehingga kelak anak tersebut tumbuh menjadi anak yang berakhlak mulia seperti dapat bertanggung jawab dalam mensosialisasikan dirinya untuk mencapai kebutuhan hidupnya dimasa mendatang. ${ }^{10}$

Pengertian anak menurut hukum pidana lebih diutamakan pada pemahaman terhadap hak - hak anak yang harus dilindungi, karena secara kodrat memiliki subtansi yang lemah dan di dalam system hukum dipandang sebagai subjek hukum yang dicangkokan dari bentuk pertanggungjawaban sebagaimana layaknya seseorang subjek hukum yang normal. Pengertian anak dalam aspek hukum pidana menimbulkan hukum perdata terhadap proses normalisasi anak dari perilaku menyimpang untuk membentuk kepribadian dan tanggung jawab yang pada akhirnya menjadikan anak tersebut berhak atas kesejahteraan yang layak dan masa depan yang baik $^{11}$.

Dengan demikian di dalam ketentuan hukum pidana telah memberikan perlindungan terhadap anak - anak yang kehilangan kemerdekaan, karena anak dipandang sebagai subjek hukum yang berada pada usia yang belum dewasa sehingga harus tetap dilindungi segala kepentingan dan perlu mendapatkan hak - hak yang khusus yang diberikan oleh negara atau pemerintah. Jadi dari berbagi definisi tentang anak di atas

\footnotetext{
${ }^{10}$ Amir Syarifuddin, Hukum Kewarisan Islam hal 17. ${ }^{11}$ ibid
}

sebenarnya yang dimaksud dengan anak berbagai konsekwensi yang di perolehnya sebagai penyandang gelar anak tersebut.

Pengangkatan Anak

Istilah anak angkat atau pengangkatan anak berkembang di Indonesia sebagai terjemahan dari bahasa Inggris "adoption" yang telah mengalami proses asimilasi ke dalam bahasa Indonesia menjadi "adopsi" (mengangkat anak) yang berarti mengangkat anak orang lain untuk dijadikan anak sendiri dan mempunyai hak yang sama dengan anak kandung. Sedangkan dalam Kamus Besar Bahasa Indonesia istilah pengangkatan anak disebut juga dengan istilah "adopsi” yang berarti pengambilan (pengangkatan) anak orang lain secara sah menjadi anak sendiri. ${ }^{12}$

Tata Cara Pengangkatan Anak

Tata cara adopsi anak telah diatur dalam Undang-Undang No. 23 Tahun 2002 tentang Perlindungan Anak yang didukung oleh Peraturan Pemerintah Nomor 54 Tahun 2007 yang dijelaskan lebih rinci dalam Peraturan Menteri Sosial Nomor 110 Tahun 2009 tentang Persyaratan Pengangkatan Anak.

Peraturan tersebut menyebut bahwa pengangkatan anak hanya dapat dilakukan untuk kepentingan terbaik bagi anak, dan tidak boleh memutus hubungan darah antara anak yang diangkat dengan orang tua kandungnya ${ }^{13}$.

Pengangkatan Anak Dalam Menurut Peraturan Pemerintah No. 54 Tahun 2007

PP No. 54 Tahun 2007 mengatur tentang Tata Cara sahnya pengangkatan anak yang harus menempuh jalur formal. Eksistensi dari pada PP tersebut juga mengenal pengangkatan anak secara adat istiadat

\footnotetext{
${ }^{12}$ Ensiklopedia Hukum Islam, 1996, VI: 27

${ }^{13}$ Irma Setyowati, Aspek Perlindungan Anak, Bumi Aksara. Hal 51
} 
masayarakat setempat, disamping pengangkatan anak secara undangundang. Sehingga kedudukan anak yang diangkat secara adat juga diakui secara sah. Jadi, dari penjelasan singkat diatas, seorang anak diluar kawin yang telah diakui dan sahkan secara hukum, dianggap sah sebagai anak angkat, sekalipun ia didsarkan pada penetapan pengadilan (pengangkatan anak secara undangundang) ataupun diangkat berdasar nilai adat istiadat masyarakat setempat. .

Pengertian Pewaris

Dalam istilah bahasa Arab hukum kewarisan disebut Faraid, yang kemudian dalam kepustakaan ilmu hukum belum terdapat keseragaman istilah yang digunakan dan sementara terdapat beberapa istilah seperti hukum waris, hukum warisan, hukum kewarisan, hukum perwarisan, hukum faraid, hukum mawaris, dan lain-lain (Amir Syarifuddin, 1984:3). Namun demikian dari segi kebahasaan, istilah yang sesuai untuk penyebutan "hukum faraid" tersebut adalah "hukum kewarisan", yang juga dipergunakan dalam Undang-Undang Nomor 7 Tahun 1989 Tentang Peradilan Agama sebagaimana telah diubah dengan Undang-Undang Nomor 3 Tahun 2006 dan Kompilasi Hukum Islam. ${ }^{14}$

Pewarisan adalah menggantikan tempat orang yang meninggal dalam hubungan-hubungan hukum kekayaannya. ${ }^{15}$ Pengertian pewaris ini mempunyai unsur yaitu :

\footnotetext{
${ }^{14}$ Rachmadi Usman, dalam dimensi Kompilasi Hukum Islam, CV Mandar Maju,Bandung,2009,hal.1

${ }^{15}$ Klaasaan J.G. dan J.E.Eggena, Hukum Waris, bagian 1, saudara dari Huwelijk-Goederan en Erfrecht,Kelompok Belajar "Esa”, Jakarta,1979 yang dimuat dalam buku Dr.J.Andy Hartanto,SH.,MH,Ir,M.M.T.Hukum Waris Kedudukan dan hak waris anak luar kawin menurut "Burgerlijk Wetboek" pasca putusan Mahkamah Konstitusi.LaksBang Justitia.Surabaya.2015.Hal.15
}

1. Seorang peninggal warisan yang pada waktu wafatnya meninggalkan kekayaan

2. Seorang atau beberapa orang ahli waris yang berhak menerima kekayaan yang ditinggalkan itu

3. Harta warisan yang berwujud harta kekayaan yang ditinggalkan oleh si peninggal warisan, yang segera akan beralih kepada ahli warisnya. ${ }^{16}$

Syarat-syarat agar dapat terjadinya pewarisan yaitu:

a. Harus ada orang yang meninggal dunia

b. Harus sudah ada ahli warisnya pada waktu meninggalnya si peninggal warisan.

c. Harus ada harta warisan yang ditinggalkan oleh si peninggal warisan.

Dengan pengaturan soal pemindahan harta peninggalan pewaris dimaksudkan untuk memberikan jaminan bahwa pemindahan kepemilikan harta peninggalan tersebut dapat berjalan secara aman, tertib dan lancar. Aman berarti secara pasti dikemudian hari tidak ada gangguan berupa gugatan atau sengketa misalnya menyangkut kepemilikan harta peninggalan, baik oleh ahli waris maupun pihak ketiga, benar-benar harta peninggalan tersebut miliknya pewaris atau tidak berada dalam sengketa. Sedangkan tertib dan lancar, berarti pemindahan harta peninggalan tadi dilakukan menurut atau

\footnotetext{
${ }^{16}$ Wirjono Prodjodikoro, Hukum Warisan di Indonesia, cet.VI,Sumur Bandung, 1974.hal.9 dimuat dalam buku ciptaan Dr.J.Andy Hartanto,SH.,MH,Ir,M.M.T.Hukum Waris Kedudukan dan hak waris anak luar kawin menurut "Burgerlijk Wetboek" pasca putusan Mahkamah Konstitusi.LaksBang Justitia.Surabaya.2015.Hal.16
} 
berdasarkan ketentuan hukum syara' atau hukum islam dalam waktu yang sesegera mungkin. ${ }^{17}$

Dengan demikian meninggalnya pewaris merupakan condition sine quanon (Teori syarat) untuk terbukanya harta warisan, karenanya meninggalnya pewaris harus nyata adanya. Apabila kematiannya tidak jelasdan berita tentang hidupnya tidak ada, maka harta itu akan tetap menjadi miliknya. Kompilasi Hukum Islam tidak menyebutkan siapa saja sebagai pewaris.

Pengertian Harta Waris

Di dalam Kompilasi

Hukum Islam membedakan antara harta peninggalan dan harta warisan. Adapun harta peninggalan adalah harta yang ditinggalkan oleh pewaris, baik itu harta benda yang dimilikinya maupun hakhaknya. Sedangkan harta warisan adalah harta bawaan ditambah bagian dari harta bersama setelah digunakan untuk keperluan pewaris selama sakit sampai meninggalnya, biaya pengurusan jenazah (tajhiz), pembayaran hutang dan pemberian untuk kerabat. Harta yang nantinya akan dibagikan kepada seorang ahli waris yang berhak yaitu harta yang telah dibersihkan dari kewajiban dan tanggung jawab pewaris yang diambilkan dari harta peninggalannya. Dengan demikian, harta yang telah dibersihkan inilah yang disebut dengan harta warisan. Pasal 85 dan 87 Kompilasi Hukum
Islam menegaskan harta kekayaan dalam sebuah perkawinan itu berasal dari harta bersama, harta bawaan dan harta milik masing-masing suami isteri. Hak kewarisan dalam Islam dapat timbul disebabkan adanya hal-hal sebagai berikut: ${ }^{18}$

Pertalian darah dan kekerabatan

Pertalian darah ini didasarkan pada ada tidaknya perkawinan yang sah, karena dengan perkawinan yang sah juga menimbulkan akibat hukum yang sah pula.Anak yang mempunyai hak kewarisan atas harta orang tua dan kerabatnya adalah anak yang sah yang dilahirkan dalam atau akibat perkawinan yang sah, termasuk di dalam pengertian ini adalah anak hasil pembuahan suami isteri yang sah dilakukan di luar rahim dan dilahirkan oleh istrinya yang sah tersebut. Bagi anak yang dilahirkan diluar perkawinan yang sah, secara perdata pertalian kekerabatan dan darahnya hanya dengan ibu dan kerabat ibunya saja.Sebagaimana tertuang dalam Pasal 186 Kompilasi Hukum Islam yang menyebutkan bahwa "anak yang lahir di luar perkawinan hanya mempunyai hubungan saling mewaris dengan ibunya dan keluarga dari pihak ibunya".Dengan demikian jelaslah bahwa pertalian darah seseorang dalam kekerabatannya ditentukan oleh terjadi tidaknya perkawinan yang sah atau di luar perkawinan. 
Pertalian perkawinan atau semenda

Hak kewarisan terjadi juga karena adanya pertalian perkawinan atau semenda, yang menyebabkan antara suami isteri mempunyai hubungan saling mewaris dengan syarat perkawinan mereka didasarkan pada akad nikah yang sah dan masih terikat perkawinan pada waktu meninggalnya suami atau isteri. Dalam pasal 174 Kompilasi Hukum Islam, selain menyebutkan ahli waris menurut hubungan darah, juga menyebutkan ahli menurut hubungan perkawinan yang terdiri atas duda dan janda.

Pertalian prasetia dengan perjanjian

Pertalian prasetia berdasarkan perjanjian ini secara umum telah digariskan dalam QS.4:33, QS.5:1 dan QS.30:6, yang mewajibkan manusia untuk memenuhi segala akad atau janji yang telah dibuat olehnya dalam pergaulan sesama. Jika sebelumnya ada pewaris yang bersumpah setia kepada saudara seagamanya, maka saudara seagamanya tersebut mempunyai hak kewarisan pula.

Pertalian lain-lainnya

$$
\text { Dalam ketentuan }
$$

Pasal 191 Kompilasi Hukum Islam, bahwa bila pewaris tidak meninggalkan ahli waris sama sekali, atau ahli warisnya tidak diketahui ada atau tidaknya, maka harta tersebut atas putusan Pengadilan Agama diserahkan penguasaannya kepada Baitul Mal (Balai Harta Keagamaan) untuk kepentingan agama Islam.

Harta Waris Menurut Hukum Positif

Harta waris di artikan sebagai hukum yang mengatur tentang kedudukan harta kekayaan seseorang setelah ia meninggal dunia (pewaris), dan cara - cara berpindahnya harta kekayaan itu kepada orang lain (ahli waris). Akibat dari pemindahan ini bagi orang-orang yang memperolehnya, baik dalam hubungan antara mereka dengan mereka, maupun dalam hubungan antara mereka dengan pihak ketiga.Dalam rangka memahami kaidahkaidah serta seluk beluk hukum waris, hampir tidak dapat dihandarkan untuk terlebih dahulu memahami beberapa istilah yang lazim dijumpai dan dikenal, di antaranya:

1. Waris; Istilah ini berarti orang yang berhak menerima pusaka (peninggalan) orang yang telah meninggal.

2. Warisan; berarti harta peninggalan, pusaka, dan surat wasiat.

3. Pewaris; adalah orang yang memberikan pusaka, yakni orang yang meninggal dunia dan meninggalkan sejumlah harta kekayaan, pusaka, maupun surat wasiat.

4. Ahli waris; yaitu orang yang menjadi waris, berarti orang-orang yang berhak menerima harta peninggalan.

5. Mewarisi; yaitu mendapat harta pusaka, biasanya segenap ahli waris adalah mewarisi harta peninggalan pewarisnya.

6. Proses pewarisan; yaitu penerusan atau penunjukan 
para waris ketika pewaris masih hidup; dan juga berarti pembagian harta warisan setelah pewaris meninggal.

Dalam hukum

positif di Indonesia, telah diatur mengenai tata cara pembagian harta warisan, dimana bagian besaran harta warisan untuk pewaris sudah diatur jumlahnya, seperti halnya dalam hukum waris BW dan hukum waris Islam.

Wujud warisan atau harta peninggalan menurut Hukum Islam sangat berbeda dengan wujud warisan menurut hukum waris Barat sebagaimana diatur dalam BW maupun menurut hukum adat. Warisan atau harta peninggalan menurut Hukum Islam yaitu "sejumlah harta benda serta segala hak dari yang meninggal dunia dalam keadaan bersih". Artinya, harta peninggalan yang diwarisi oleh para ahli waris adalah sejumlah harta benda serta segala hak, "setelah dikurangi dengan pembayaran hutang-hutang pewaris dan pembayaranpembayaran lain yang diakibatkan oleh wafatnya si peninggal waris.

Dalam hukum waris BW, wujud harta peninggalan meliputi "seluruh hak dan kewajiban dalam lapangan hukum harta kekayaan yang dapat dinilai dengan uang". Jadi harta peninggalan yang akan diwarisi oleh para ahli waris tidak hanya meliputi halhal yang bermanfaat berupa aktiva atau keuntungan, melainkan juga termasuk hutang-hutang si pewaris yang merupakan pasiva dari harta kekayaan yang ditinggalkan, sehingga "kewajiban membayar hutang pada hakikatnya beralih juga kepada ahli waris".

Demikian pula pada hukum adat, pembagian harta warisan tidak selalu ditangguhkan sampai semua hutang si peninggal warisan dibayar. Artinya, harta warisan yang dapat beralih kepada para ahli waris tidak selalu dalam keadaan bersih setelah dikurangi hutang-hutang pewaris, melainkan dapat saja ahli waris menerima harta warisan yang di dalamnya tercakup kewajiban membayar hutang-hutang pewaris.

Kedudukan Harta Waris Orang Tua Terhadap Anak angkat menurut Hukum Positif

Kedudukan anak angkat menurut hukum islam tetap sebagai anak angkat yang sah berdasarkan keputusan pengadilan dengan tidak memutuskan hubungan nasab dengan orang tua kandungnya, dikarenakan prinsip pengangkatan anak menurut hukum islam adalah merupakan manifestasi keimanan yang terwujud dalam bentuk memelihara anak orang lain sebagai anak dalam bentuk pengsuh anak dengan memberikan segala kebutuhan hidupnya..kedudukan hukum islam diartikan sebagai berikut dengan ketentuan:

a. Hukum Islam tidak melarang adanya lembaga adopsi (pengangkatan anak) bahkan membenarkan dan menganjurkan demi untuk kesejahteraan anak dan kebahagiaan orang tua.

b. Perlu diadakanya peraturan perundang-undangan tentang 
pengangkatan anak yang memadahi.

c. Supaya diusahakan adanya penyatuan istilah pengangkatan anak dengan meniadakan istilah-istilah lain.

d. Pengangkatan anak jangan memutuskan hubungan antara anak yang diangkat dengan orang tua kandungnya.

e. Hubungan kekayaan/ kebendaan antara anak yang di angkat dan orang yang mengangakat dianjurkan agar dalam hubungan hibah dan wasiat.

f. Pengangakatan anak yang terdapat dalam hukum adat hendaknya diusahakan agar tidak bertentangan dengan hukum Islam.

g. Pengangkatan anak oleh warga negara asing supaya diadakan pembatasan yang lebih ketat.

h. Tidak dapat dibenarkannya pengangkatan anak oleh orang yang berlainan agama.

\section{PENUTUP}

Kesimpulan

Menurut PP No. 54

Tahun 2007 mengatur tentang Tata Cara sahnya pengangkatan anak yang harus menempuh jalur formal. Eksistensi dari pada PP tersebut juga mengenal pengangkatan anak secara adat istiadat masayarakat setempat, disamping pengangkatan anak secara undang-undang. Sehingga kedudukan anak yang diangkat secara adat juga diakui secara sah.

Kedudukan anak angkat menurut hukum positif tetap sebagai anak angkat yang sah berdasarkan keputusan pengadilan dengan tidak memutuskan hubungan nasab dengan orang tua kandungnya, dengan demikian anak angkat didalam keluarga memiliki kedudukan yang sama dengan anak kandung atau anak yang terlahir dari orang tua angkatnya termasuk juga mengenahi kesamaan hak dan kewajiban yang dimiliki oleh anak angkat dalam warisan harta orang tua.

Saran

Kepada orang tua angkat, penulis menyarankan agar mengesahkan pengangkatan anak menurut Undang-Undang dengan cara mendaftarkannya di Pengadilan Negeri agar pengangkatan anak yang telah dilakukan berdasarkan hukum adat Osing tersebut dapat diakui dan sah menurut hukum positif yang berlaku sehingga kedudukan anak dengan orang tua angkatnya menjadi kuat karena Negara telah mengakui serta melindungi hak-hak dan kewajiban anak dengan orang tua angkatnya.

Kepada penulis selanjutnya, bisa melakukan penelitian terhadap hukum masyarakat adat lainnya yang ada di Pulau Jawa. Karena masyarakat adat yang ada di Pulau Jawa sendiri sebenarnya banyak sekali, tetapi masih sedikit yang melakukan penelitian khusus mengenai hukum waris adatnya. Tujuannya sebagai pembanding hukum adat yang ada di Jawa Timur ataupun di Pulau Jawa yang 
menurut penulis sangat kaya dengan keanekaragaman masyarakat adatnya.

Daftar Pustaka

Literatur

Amir Syarifuddin, Hukum Kewarisan Islam. Kencana: Jakarta tahun 2004.

Hartanto, Hukum waris kedudukan dan hak waris anak luar kawin menurut Burgerlijk Wetboek pasca putusan Mahkamah Konstitusi. laksbang justicia: Surabaya, Tahun 2015.

Irma Setyowati Soemitro, Aspek Perlindungan Anak, Bumi Aksara: Jakarta, tahun 1990.

Johny Ibrahim, Teori \& Metode Penelitian Hukum Normatif. Banyu Media Publishing: Malang, Tahun 2006.

J.E. Eggena, Hukum Waris. Kelompok Belajar Esa: Jakarta,Tahun 1979.

Peter Mahmud Marzuki, Penelitian Hukum. Kencana: Jakarta, Tahun 2010.

Rachmadi Usman, Hukum Kewarisan Islam dalam dimensi Kompilasi Hukum Islam. Mandar Maju: Bandung, Tahun 2009.

Rachmad Budiono, Pembaharuan Hukum Kewarisan Islam Di Indonesia.
Cetakan Pertama,Citra Aditya Bakti: Bandung, Tahun 1999.

Soerojo Wignjodipoero, Pengantar dan Asas-Asas Hukum Adat, Gunung Agung, Jakarta, 1992

Tolib Setiady, Intisari Hukum Adat Indonesia. Alfabeta: Bandung, Tahun 2009.

Wirjono Prodjodikoro, Hukum Warisan di Indonesia. Sumur: Bandung,Tahun 1974.

PERUNDANG-UNDANGAN:

Peraturan Pemerintah Nomor 54 Tahun 2007

UUD 1945

Undang-Undang Nomor 1 Tahun 1974 Tentang Perkawinan

\section{INTERNET}

http://Belajarhukumperdata.blogspot.co.id/ 2013/07/pengankatan-anak-adopsi/ http://Dunkdaknyonk.blogspot.co.id/Kedu dukan-Hukum-dan-Hak-WarisAnak-Angkat-(Anak Pungut,Adopsi)

http://jadipintar.com/2013/08/KedudukanHukum-dan-Hak-WarisAnakangkat-Anak-Pungut-Adopsi 